Another World 


\section{Another World}

NINETEENTH-CENTURY ILLUSTRATED PRINT CULTURE

Patricia Mainardi 
Copyright $\odot 2017$ by Patricia

Mainardi.

All rights reserved.

This book may not be reproduced, in whole or in part, including illustrations, in any form (beyond that copying permitted by Sections 107 and 108 of the U.S. Copyright Law and except by reviewers for the public press), without written permission from the publishers. yalebooks.com/art

Designed by Leslie Fitch

Set in Crimson and Source Sans Pro type by Leslie Fitch

Printed in China by Regent

Publishing Services Limited

Library of Congress Control

Number: 2016930356

ISBN 978-0-300-21906-7 eISBN 978-0-300-22378-1

A catalogue record for this book is available from the British Library. This paper meets the requirements of ANSI/NISO Z 39.48-1992 (Permanence of Paper).

$\begin{array}{llllllllll}10 & 9 & 8 & 7 & 6 & 5 & 4 & 3 & 2 & 1\end{array}$

Jacket illustrations: (front) Grandville, Cast Shadows [Les ombres portées] (fig. 49); (back) Jules Gaildrau, Lighted Kiosks. New Stalls for the Sale of Newspapers on the Boulevards [Kiosques lumineux. Nouveaux bureaux pour la vente des journaux sur les boulevards] (fig. 83)

Frontispiece: Charles-Joseph Traviès, You Have to Admit That the Head of State Looks Pretty Funny (detail of fig. 48) 